\title{
VZTAH K OČEKÁVANÉMU DÍTĚTI A JEHO SOUVISLOSTI S VYBRANÝMI INTRA- A INTERPERSONÁLNÍMI CHARAKTERISTIKAMI ŽEN V TŘETÍM TRIMESTRU TĚHOTENSTVÍ1
}

\author{
Petra Daňsová, Zuzana Masopustová, Lucie Miškóciová, Lenka Lacinová
}

\begin{abstract}
Abstrakt
Studie se zabývá vztahem těhotných žen $\mathrm{k}$ jejich očekávanému dítěti. U vzorku 339 žen ve třetím trimestru těhotenství byla zkoumána spojitost vztahu k očekávanému dítěti s úzkostností, depresivitou, kvalitou partnerského vztahu a s vyhýbavostí a úzkostností citové vazby k partnerovi. Byl kontrolován vliv parity, plánovanosti a chtěnosti dítěte a věku matky. Nejsilnějším prediktorem vztahu $\mathrm{k}$ očekávanému dítěti byla kvalita partnerského vztahu - ženy, které hodnotily svůj partnerský vztah jako kvalitní, pocitovaly silnější vztah k očekávanému dítěti. Byl prokázán také vliv parity (prvorodičky pocitovaly $\mathrm{k}$ očekávanému dítěti silnější vztah než vícerodičky) a plánovanosti dítěte (ženy, jejichž těhotenství bylo plánované, pocit’ovaly k očekávanému dítěti mírně silnější vztah). Ve výzkumu byla poprvé použita nová škála $\mathrm{k}$ měření vztahu $\mathrm{k}$ očekávanému dítěti, která překonává některé limity dosavadních metod. Metoda měři různé aspekty vztahu $\mathrm{k}$ dítěti v oblasti emoční, kognitivní i behaviorální.
\end{abstract}

Klíčová slova: vztah k očekávanému dítěti, těhotenství, úzkostnost, depresivita, kvalita partnerského vztahu, vyhýbavost citové vazby, úzkostnost citové vazby

\section{MOTHER-FOETUS RELATIONSHIP AND ITS CONNECTION WITH CHOSEN INTRA- AND INTERPERSONAL CHARACTERISTICS OF WOMEN IN THIRD TRIMESTER OF PREGNANCY}

\begin{abstract}
Our study deals with the mother-foetus relationship (MFR) and its connection to chosen mother's characteristics. The relationship of MFR and anxiety, depression, quality of partnership, attachmentrelated avoidance and attachment-related anxiety was investigated on a sample of 339 pregnant women (third trimester). The effect of parity, pregnancy planning, desire for a child and the women's age were taken into account. Quality of the partnership was the strongest predictor of MFR. Women who considered their relationship with their partner to be functional had a stronger relationship to their unborn baby. Primiparae had a slightly stronger MFR than multiparae and a planned pregnancy is associated with a slightly stronger MFR. The present study uses the new scale of MFR for the first time. The scale overcomes some limits of the older scales and measures different aspects of MFR including emotional, cognitive and behavioural one.
\end{abstract}

Keywords: mother-foetus relationship, pregnancy, anxiety, depressivity, quality of partnership, attachment-related avoidance, attachment-related anxiety

Došlo do redakce: 4. 6. 2016

Schváleno k publikaci: 4. 4. 2018

\footnotetext{
${ }^{1}$ Vznik studie byl podpořen projektem "Yummy mummy" ideál a skutečnost: Od rozdílů v osobnosti matek a způsobu péče o děti k batolecímu vývoji a citové vazbě (GA16-11015S) a projektu specifického výzkumu DOMOV, CESTY, PARTICIPACE 2018 (MUNI/A/0939/2017).
} 


\section{Úvod}

Vztah k očekávanému dítěti poprvé definovala Cranleyová (1981) jako míru, ve které se žena angažuje v chování zahrnujícím afiliaci a interakci s ještě nenarozeným dítětem. Další autoři pak zdůrazňují v různé míře pocity, chování a postoje matky k dítěti, což se odráží také v používaných nástrojích měření (např. Condon, 1993; Müller, 1993). Shieh a kol. (2001) na základě zhodnocení literatury vymezují tři klíčové aspekty vztahu k dítěti, kterými jsou kognitivní složka (touha poznat a znát dítě), afektivní složka (potěšení z přemýšlení o dítěti nebo interakcemi s dítětem) a altruistická složka (touha dítě chránit). Poslední ze složek je tedy behaviorální, protože vede matku $\mathrm{k}$ chování majícím za cíl bezpečí a ochranu nenarozeného dítěte. Vztah $\mathrm{k}$ dítěti je současnými autory definován šířeji jako pocit'ované pouto matky $\mathrm{k}$ dítěti, které je charakterizováno pozitivními emocemi, chováním a postoji a potřebou dítě chránit a pečovat o něj (např. Walsh, 2010). Ukazuje se, že vztah k očekávanému dítěti může mít vliv na další vývoj vztahu či kvalitu interakce matky s dítětem po narození (např. Cranley, 1981; Tsujino, Higa, \& Inuihara, 2002; Siddiqui \& Hägglöf, 2000), proto se studie snaží nalézt faktory, které jej pozitivně či negativně ovlivňují. Mezi zkoumané faktory patří faktory demografické, gestační a teoretické (pro shrnutí např́. Yarcheski, Mahon, Yarcheski, Hanks, \& Cannella, 2009). Cílem této práce je vytvořit a ověřit metodu pro měření vztahu $\mathrm{k}$ očekávanému dítěti použitelnou v českém prostředí a zmapovat souvislosti s vybranými faktory všech tř́ uvedených oblastí.

Konstrukt bývá v zahraničních studiích označován termíny prenatal attachment, antenatal attachment či maternal-foetal attachment (pro shrnutí napřr. Van den Bergh \& Simons, 2009). Užívání termínu citová vazba (attachment) je v tomto kontextu zavádějící (např. Walsh, 2010). Klasická teorie citové vazby (Bowlby, 1969) se týká vztahu $k$ pečující osobě, zatímco dotazníky měřící tzv. maternal-foetal attachment se ptají pečující osoby na jeji vztah k dítěti. Vztah k očekávanému dítěti je spíše součástí komplementárního behaviorálního systému péče a ochrany (caregiving) (Walsh, 2010), který má své kořeny v attachmentovém systému, vyvíjí se během adolescence a proměňuje se právě při přechodu $\mathrm{k}$ rodičovské roli (George \& Solomon, 1996). Termínu citová vazba se tedy budeme při popisu vztahu ženy k očekávanému dítěti vyhýbat. Při pojmenování konstruktu vycházíme z pojmu mother-foetus relationship (Van den Bergh \& Simons, 2009), který překládáme jako vztah k očekávanému ditěti. Termín dle našeho názoru vystihuje podstatu měřeného konstruktu lépe než vztah mezi matkou a plodem, nebot' hovoří o ditěti, tedy o lidské bytosti, k níž lze mít vztah. Předložkou $k$ zdůrazňujeme fakt, že popisovaný konstrukt je založen na informacích zjišt'ovaných pouze od jedné strany - od matky (a nejedná se tedy o vztah $s$ dítětem či mezi matkou a dítětem v pravém slova smyslu).

Meta-analýza Yarcheski, Mahona, Yarcheskiho, Hankse a Cannelly (2009) dělí faktory, které se vztahem k očekávanému dítěti souvisí, do tří oblastí: demografické, gestační a teoretické. Mezi demografické faktory patří zejména věk, vzdělání, socioekonomický status či rodinný stav ženy. Ve většině případů se ukazuje jen slabý či žádný vztah, př́ípadně nejsou výsledky zcela jednoznačné (např. Cannella, 2005; Condon \& Corkindale, 1997; Damato, 2004; Lindgren, 2001). Na základě výsledků meta-analýzy Yarcheski a kol. (2009) je velmi mírně silnější vztah k očekávanému dítěti u žen ve vyšším věku, u žen s vyšším vzděláním, vyšším socioekonomickým statusem a u žen vdaných.

Z faktorů gestačních je zkoumáno zejména gestační stáří, parita ženy, plánovanost těhotenství a rizikovost těhotenství. I zde nejsou zjištění zcela konzistentní (např. Berryman \& Windridge, 1996; Condon \& Corkindale, 1997; Damato, 2004). Podle meta-analýzy Yarcheski a kol. (2009) je souvislost těchto faktorů pouze slabá, prvorodičky, ženy, které 
těhotenství plánovaly a ženy, jejichž těhotenství je méně rizikové, mají mírně silnější vztah k očekávanému dítěti než ženy druhorodičky, ženy s neplánovaným těhotenstvím a s více rizikovým těhotenstvím. Chtěnost těhotenství, která by mohla být vedle plánovanosti také důležitá, doposud zkoumána nebyla. Gestační stáří je podstatné z hlediska zkoumání souvislostí s dalšími faktory. Condon (1993) uvádí, že vztah k očekávanému dítěti se vytváří v průběhu těhotenství, kdy postupně narůstá zabývání se dítětem, vytváŕí se mentální reprezentace očekávaného dítěte, čímž dochází $\mathrm{k}$ rozvoji citového vztahu. $\mathrm{Na}$ počátku těhotenství je vztah $\mathrm{k}$ očekávanému dítěti více nejasný a abstraktní. S postupným růstem plodu a tím, jak se plod začíná projevovat (např. pohyby), může nastávající matka své dítě vnímat konkrétněji a více s ním také interagovat. Vztah $\mathrm{k}$ očekávanému dítěti je v pozdějších fázích těhotenství silnější a více intenzivní (Yarcheski et al., 2009).

Poslední oblastí faktorů ovlivňujících vztah k očekávanému dítěti jsou podle metaanalýzy Yarcheski a kol. (2009) faktory teoretické, kam autoři řadí depresivitu ženy, úzkostnost ženy, sociální oporu, sebehodnocení a další, tedy faktory vztahující se k prožívání a postojům ženy jak k sobě, tak k blízkým lidem. Depresivní symptomy jsou charakteristické negativním prožíváním, negativním pohledem na sebe i na svět kolem, což může bránit ženě ve vytvoření pozitivního vztahu $\mathrm{k}$ očekávanému dítěti. Přri měření na počátku těhotenství obvykle není souvislost mezi vztahem k očekávanému dítěti a depresivitou nalezena, případně je pozitivní (např. Barone et al., 2014; Tsartsara \& Johnson, 2006). Přri měření ke konci těhotenství pak obvykle platí, že čím více negativních prožitků, tím slabší vztah k očekávanému dítěti (Condon \& Corkindale, 1997; Goecke et al., 2012; Lindgren, 2001; McFarland et al., 2011), což potvrzují také výsledky meta-analýzy (Yarcheski et al., 2009). Výskyt depresivních symptomů je často doprovázen také zvýšenou mírou úzkosti (napřr. Austin, Tully, \& Parker, 2007; Coelho, Murray, Royal-Lawson, \& Cooper, 2011). Ženy s vyšší mírou úzkostných symptomů mají obvykle nižší vztah k očekávanému dítěti (napřs. Condon \& Corkindale, 1997; Yarcheski et al., 2009).

Kromě faktorů na straně ženy samotné se jako podstatná ukazuje také sociální opora $\mathrm{v}$ době těhotenství, která může pozitivně ovlivnit utváření vztahu k očekávanému dítěti. Podle výsledků meta-analýzy Yarcheski a kol. (2009) je sociální opora jedním z nejsilnějších prediktorů, nicméně pouze se střední velikostí účinku. Autoři poukazují na potřebu více se zaměřit specificky na emoční oporu (Yarcheski a kol., 2009), zejména ve vztahu s partnerem. Ukazuje se, že ženy, které jsou ve vztahu s partnerem více spokojené, mají silnější vztah k očekávanému dítěti než ženy, které spokojené nejsou (např. Barone, Lionetti, \& Dellagiulia, 2014; Wachter, 2002). Spokojenost ve vztahu a opora od partnera je tak podstatná pro to, aby se žena mohla připravovat na nastávající mateřskou roli a mohla si vytvářet pozitivní vztah $\mathrm{k}$ dítěti.

Vztah k očekávanému dítěti je veden systémem péče (Walch, 2010), proto došlo k rozššřření zájmu výzkumníků také na citovou vazbu ženy. Mentální reprezentace sebe a druhých, které jsou součástí attachmentového systému, ovlivňují postoj ženy k blízkým lidem a k chápání sociálního světa obecněji (Mikulincer \& Shaver, 2007). Lidé s jistou citovou vazbou nahlížejí na sebe i na druhé jako na hodnotné a hodné citu, zájmu a podpory, snáze navazují blízké vztahy a není pro ně těžké být závislý na druhém nebo když je někdo závislý na nich (Hazan \& Shaver, 1987). Pro lidi s vyhýbavostí citové vazby je typické vnímání druhých jako nedostupných, není jim př́jemné být na nich závislý nebo aby byli druzí závislí na nich, snaží se být více autonomní a na druhé se př́liš nespoléhat. U lidí s úzkostností citové vazby jsou typické obavy z nedostupnosti druhých, obavy z opuštění druhými. Často také touží po nadměrné hladině blízkosti ve vztahu (Hazan \& Shaver, 1987). Tyto představy 
o fungování vztahů se mohou přenášet také na vztah $\mathrm{k}$ očekávanému dítěti a ovlivňovat jeho utváření. Výzkum Zachariaha (1994) nenašel souvislost mezi vztahem k očekávanému dítěti a citovou vazbou ženy k její vlastní matce, ani citovou vazbou k partnerovi. Souvislost byla nalezena ve studii Mikulincera a Floriana (1999), kteří zjistili, že v prvním a druhém trimestru těhotenství mají ženy s jistým typem citové vazby silnější vztah $\mathrm{k}$ očekávanému dítěti než ženy s vyhýbavým nebo úzkostně-ambivalentním typem citové vazby. Ve třetím trimestru se již ženy s jistým typem nelišily od žen s úzkostně-ambivalentním typem a jejich vztah $\mathrm{k}$ dítěti byl silnější pouze oproti ženám s vyhýbavým typem citové vazby. Zatímco u žen s jistým nebo úzkostně-ambivalentním typem vztah $\mathrm{k}$ očekávanému dítěti s postupujícím těhotenstvím rostl, u žen s vyhýbavým typem citové vazby se objevil vzorec obrácené křivky U: nárůst vztahu ve druhém trimestru následovaný poklesem ve třetím trimestru. Tyto výsledky byly doloženy také v longitudinálním výzkumu stejných autorů (Mikulincer \& Florian, 1999). Ve studii Walshe, Heppera a Marshalla (2014), která pojímala citovou vazbu v dimenzích úzkostnosti a vyhýbavosti nikoli kategoricky jako předchozí studie, bylo zjištěno, že čím vyšší míra vyhýbavosti citové vazby, tím slabší vztah $\mathrm{k}$ očekávanému dítěti. Spojitost mezi úzkostností citové vazby a vztahem k očekávanému dítěti nalezena nebyla (Walsh, Hepper, \& Marshall, 2014).

Př́íciny dosavadních nejednotných zjištění je možné hledat $\mathrm{v}$ samotné podstatě konstruktu a ve způsobech jeho měření. Jak již bylo zmíněno výše, napříč různými výzkumy se liší nejen způsob označování konstruktu, ale i podoba a obsah jednotlivých metod. Např́klad původní metoda Maternal Fetal Attachment Scale (Cranley, 1981) je kritizována za př́lišné zaměření se na chování matky k dítěti a opominutí emoční složky vztahu. Metoda The Maternal Antenatal Attachment Scale (MAAS, Condon, 1993) obsahuje dvě dimenze, kterými jsou kvalita vztahu a intenzita vztahu, není tedy opět rozlišováno mezi různými aspekty vztahu k dítěti. Metoda Prenatal Attachment Inventory (PAI, Müller, 1993) je podle původní studie autorů jednodimenzionální, další studie navrhují vícedimenzionální strukturu, napřr. tř́́dimenzionální struktura $\mathrm{s}$ faktory interakce $\mathrm{s}$ dítětem, diferenciace sebe od dítěte a očekávání, tedy přání, fantazie a plány do budoucna ohledně dítěte (Pallant, Haines, Hildingsson, Cross, \& Rubertsson, 2014). Je patrné, že různé metody akcentují různé aspekty vztahu k očekávanému dítěti. Lze se navíc domnívat, že za rozdílnými výsledky stojí také odlišné fáze těhotenství, $\mathrm{v}$ nichž je vztah $\mathrm{k}$ očekávanému dítěti měřen. Metody $\mathrm{k}$ měření vztahu k očekávanému dítěti mohou měřit něco jiného právě v závislosti na fázi těhotenství, a proto někteří autoři doporučují měřit vztah $\mathrm{k}$ očekávanému dítěti až $\mathrm{v}$ jeho pozdějších fázích (např. Yarcheski et al., 2009).

Cílem studie je vytvořit metodu pro měření vztahu k očekávanému dítěti použitelnou v českém prostředí tak, aby reflektovala různé aspekty vztahu k očekávanému dítěti. Dalším cílem je prozkoumat souvislost depresivity a úzkostnosti ženy, její citové vazby k partnerovi a vnímané kvality partnerského vztahu se vztahem $\mathrm{k}$ očekávanému dítěti u těhotných žen v třetím trimestru těhotenství. Předpokládáme, že čím vyšší míra depresivity a úzkostnosti ženy, tím bude její vztah k očekávanému dítěti slabší. Dále předpokládáme, že čím kvalitnější partnerský vztah bude žena vnímat, tím bude její vztah k dítěti silnější, a čím vyšší míra úzkostnosti i vyhýbavosti citové vazby k partnerovi, tím slabší vztah k očekávanému dítěti. Bude kontrolován vliv parity, chtěnosti dítěte a plánovanosti těhotenství a také věku ženy (např. Condon \& Corkindale, 1997; Yarcheski et al., 2009). 


\section{METODY}

Studie vznikla v rámci longitudinálního projektu DOMOV - děti, otcové a matky o vývoji Institutu výzkumu dětí, mládeže a rodiny Fakulty sociálních studií Masarykovy univerzity. Sběr dat byl realizován pomocí online dotazníkového šetření probíhajícího od července roku 2014 do dubna 2015.

\section{Výzkumný soubor a procedury sběru dat}

Výzkumný soubor se skládá z 339 respondentek. Pro účely práce bylo ze vzorku čítajícího 348 žen vyřazeno 6 respondentek, které čekaly dvojčata. Studie Damata (2004) sice nenalezla rozdíl ve vztahu $\mathrm{k}$ jednomu očekávanému dítěti a $\mathrm{k}$ očekávaným dvojčatům, ale nelze zaručit, že tento rozdíl neexistuje ani v našem vzorku. Vzorek žen těhotných s dvojčaty je př́liš malý pro ověření př́ípadných rozdílů. Dále byly $\mathrm{z}$ analýzy vyřazeny 3 aktuálně nezadané ženy, u kterých nebylo možné ověřit faktory související s partnerským vztahem. Vzorek tvoří ženy v třetím trimestru těhotenství od 17 do 45 let $(\mathrm{M}=29,63 ; \mathrm{SD}=4,51)$, které jsou v partnerském vztahu. Jsou zastoupeny respondentky se všemi typy dosaženého vzdělání - základní $(\mathrm{N}=11 ; 3,4 \%)$, vyučení bez maturity či s maturitou $(\mathrm{N}=12 ; 3,6 \%)$, středoškolské vzdělání bez maturity $(\mathrm{N}=8 ; 2,5 \%)$, střední odborná škola $\mathrm{s}$ maturitou $(\mathrm{N}=98 ; 30,1 \%)$, gymnázium $(\mathrm{N}=22 ; 6,7 \%)$, vyšší odborná škola $(\mathrm{N}=16 ; 4,9 \%)$ a vysokoškolské vzdělání (N=159; 48,8 \%). S biologickým otcem dítěte žilo ve společné domácnosti 332 žen (97,9 \%). Více než polovinu výzkumného souboru tvoří prvorodičky (206 žen; 60,8\%). Ze 133 (39,2\%) vícerodiček má $110(32,4 \%)$ žen jedno dítě, $32(9,4 \%)$ žen dvě děti a po jedné ženě $(0,3 \%)$ tři, čtyři nebo sedm dětí.

V převážné většině případů (280 žen; 82,6 \%) si dle výpovědi ženy dítě přála jak ona, tak její partner. Dalších $24(7,1 \%)$ žen uvedlo, že dítě chtěly více ony než jejich partner, 18 $(5,3 \%)$ žen naopak uvedlo, že si dítě více přál partner. Pouze $11(3,2 \%)$ žen pak vypovědělo, že si dítě nepřály ani ony, ani jejich partner, a $6(1,8 \%)$ žen nechtělo odpovídat. Chtěnost dítěte byla dichotomizována na kategorie: 1 - spíše chtěné dítě $(\mathrm{N}=304 ; 91,3 \%$; dítě si přála žena i partner nebo spíše žena než partner) a 0 - spíše nechtěné dítě ( $\mathrm{N}=29 ; 8,7 \%$; dítě si přál spíše partner nebo si jej nepřála ani žena, ani partner). Hodnoty šesti žen, které uvedly, že nechtějí odpovídat, byly označeny jako chybějící. 70 (20,7 \%) žen dítě neplánovalo, 90 (26,6 \%) respondentek se o početí snažilo méně než měsíc a $108(32 \%)$ respondentek měsíc až půl roku. 7 měsíců až rok se o početí snažilo 27 (8\%) respondentek, více než rok 20 $(5,9 \%)$ respondentek, více než dva roky $9(2,7 \%)$ respondentek a více než tři roky pak 14 $(4,1 \%)$ respondentek. Plánovanost dítěte byla také dichotomizována na 0 - neplánované dítě $(\mathrm{N}=70,20,7 \%), 1$ - plánované dítě $(\mathrm{N}=268,79,3 \%)$.

Vzorek byl získán samovýběrem, respondentky byly oslovovány prostřednictvím facebookových stránek projektu, diskusních fór zabývajících se těhotenstvím a mateřstvím a také prostřednictvím informačních letáků distribuovaných do mateřských center, porodnic, porodním asistentkám, gynekologům a praktickým lékařủm.

\section{Metody}

Pro měření vztahu $k$ očekávanému dítěti byla týmem projektu DOMOV vytvořena nová škála, která se inspirovala dosud používanými metodami PAI (Müller, 1993) a MAAS (Condon, 1993). V souladu s výše uvedenými výhradami $\mathrm{k}$ nevhodně voleným názvưm konstruktu byla metoda nazvána jako Vztah k očekávanému dítěti (ad Př́loha 1). Dotazník obsahuje 25 položek hodnocených na škále $0-4$ (od nikdy po velmi často). Položky byly vytvářeny se snahou zkonkretizovat tvrzení (mluvit k dítěti vs. povídat dítěti, co zrovna délám 
nebo co se děje kolem), vynechat irelevantní údaje komplikující odpovídání, které byly užívané $\mathrm{v}$ jiných metodách (např. v poslednich dvou týdnech; když jsem sama), vyhnout se podmínkovým položkám, které jsou obsažené zejména $\mathrm{v}$ dimenzi intenzity škály MAAS (jaké měla žena pocity $z$ dítěte, když dělala nějakou specifickou činnost), a sjednotit formulace tvrzení pro možnost jednotného formátu odpovídání. Kromě položek vycházejících z metod MAAS a PAI tak, aby zachovaly klíčové oblasti měřené těmito metodami, bylo přidáno dalších 10 položek, které se týkají například starosti o dítě, přizpůsobení životního stylu matky dítěti nebo vnímaných reakcí dítěte. Tyto aspekty podle našeho názoru přispívají k vyšší obsahové validitě metody, nebot' pokrývají konstrukt šířeji než dosud používané metody, a zahrnují jak emoční, tak kognitivní a behaviorální složku vztahu k dítěti. Čím vyššího celkového skóru žena dosáhne, tím silnější vztah k očekávanému dítěti pocituje.

Úzkostnost byla měřena škálou Generalized Anxiety Disorder 7 (GAD-7) (Spitzer, Kroenke, Williams, \& Löwe, 2006), která byla pro účely projektu DOMOV přeložena do češtiny a tato verze byla ověřena zpětným překladem. Metoda obsahuje 7 položek - popisů symptomů úzkosti, u kterých respondentky na škále 0 - 3 (od vůbec ne po téměř každý den) hodnotí, nakolik je v posledních dvou týdnech obtěžovaly (př. Pocit nervozity, úzkosti nebo napětí (pocit jako na jehlách.). Čím vyšší skóre na škále, tím vyšší míra úzkosti ženy. V původní anglické verzi má škála výbornou reliabilitu (Cronbachova $\alpha=0,92)$, konstruktovou a faktorovou validitu, a také senzitivitu a specificitu (Spitzer et al., 2006).

Depresivita byla měřna škálou Patient Health Questionnaire 9 (PHQ-9) (Kroenke, Spitzer, \& Williams, 2001), která byla rovněž přeložena do češtiny v rámci projektu DOMOV (Daňsová, Masopustová, Hanáčková, Kicková, \& Korábová, 2016). Metoda obsahuje 9 položek (př. Malý zájem nebo potěšení cokoli dělat.) na škále 0 - 3 (od vůbec ne po téměř každý den). Respondentky hodnotí, nakolik je $\mathrm{v}$ posledních dvou týdnech obtěžovaly jednotlivé symptomy deprese. Čím vyšší skóre, tím větší míra depresivní symptomatiky. Výsledky studie Martinové, Riefové, Klaiberga a Braehlera (2006) dokládají konstruktovou validitu dotazníku a vhodnost jeho použití pro klinickou i běžnou populaci. Byla prokázána také jednofaktorovost a vysoká reliabilita $(\alpha=0,83)$ původní škály (Cameron, Crawford, Lawton, \& Reid, 2008).

Pocit'ovaná kvalita manželství či partnerství byla měřena dotazníkem Revised Dyadic Adjustment Scale (RDAS) (Busby, Christensen, Crane, \& Larson, 1995), přeloženým pro účely studie do češtiny. Metoda obsahuje 14 položek, z nichž 13 je hodnoceno na škále 0 - 5 (od nikdy se neshodneme po vždy se shodneme nebo od neustále po nikdy či od nikdy po častěji než jednou denně) a jedna položka na škále 0 - 4 (od nikdy po každý den). Škála hodnotí tři aspekty partnerského fungování - konsenzus, spokojenost a kohezi. Je možné získat součtové skóre pro jednotlivé subškály nebo pro celou škálu. Čím vyšší skór, tím vyšší spokojenost a nižší distres ve vztahu. Originální metoda vykazuje vysokou reliabilitu a validitu a dobře rozlišuje páry s různou mírou distresu ve vztahu (Busby et al., 1995; Anderson et al., 2014).

Citová vazba k partnerovi byla měřena metodou Experiences in Close Relationships Relationship Structures Questionnaire (ECR-RS) (Fraley, Heffernan, Vicary, \& Brumbaugh, 2011), kterou do češtiny přeložili Michalčáková, Lacinová, Bouša a Schlesingerová (2011). Škála zjišt'uje jistotu citové vazby $\mathrm{v}$ různých vztahových kontextech - v případě tohoto výzkumu v partnerském vztahu - jako míru vyhýbavosti a úzkostnosti citové vazby. Dimenze vyhýbavosti vyjadřuje míru, do jaké je respondentce nepř́ijemné se partnerovi otevř́t a být na něm závislá, dimenze úzkostnosti pak tendenci respondentky dělat si starosti související s dostupností a vnímavostí partnera. Škála obsahuje 9 položek (6 pro vyhýbavost, 3 pro 
úzkostnost), u kterých žena hodnotí míru svého souhlasu na škále 1 - 7 (od silně nesouhlasím po silně souhlasím). Čím vyšší skóre, tím vyšší míra vyhýbavosti či úzkostnosti, potažmo nejistoty citové vazby. Byla prokázána vysoká reliabilita (pro celou škálu i jednotlivé subškály $\alpha>0,80)$ a validita původní škály. Dotazník významně souvisí s fungováním partnerského vztahu a s pocit’ovaným závazkem a spokojeností v něm (Fraley et al., 2011).

Pro zhodnocení prediktivní validity nově vytvořené metody byl ve 3 měsících věku dítěte měřen vztah žen $\mathrm{k}$ narozenému dítěti. Pro měření vztahu $\mathrm{k}$ dítěti po narození byla použita metoda Post-Partum Bonding Questionnaire (PPBQ, Brockington, Fraser, \& Wilson, 2006). Jedná se o 25 položkovou metodou (Př. Cítím se citově blízko svému dítěti.; 0 - vždy po 5 - nikdy) zaměřenou na hodnocení poruch ve vztahu matka-dítě.

\section{VÝSLEDKY}

Popisné charakteristiky a hodnoty koeficientu vnitřní konzistence pro použité metody jsou uvedeny v tabulce 1. Distribuce hodnot dimenzí a celkových skórů metod, jakož i distribuce položek jsou unimodální. Hodnoty koeficientů vnitřní konzistence jsou pro všechny metody uspokojivé.

Tab. 1 Popisné charakteristiky a koeficienty vnitřní konzistence metod

\begin{tabular}{lcccccc}
\hline & M(SD) & Min. & Max. & $\alpha$ & $\begin{array}{c}\text { Počet } \\
\text { položek }\end{array}$ & $\mathrm{N}$ \\
\hline Vztah k očekávanému dítěti & $2,82(0,49)$ & 1,09 & 4,00 & 0,88 & 22 & 270 \\
Úzkostnost citové vazby & $2,29(1,41)$ & 1,00 & 7,00 & 0,85 & 3 & 329 \\
Vyhýbavost citové vazby & $2,05(1,07)$ & 1,00 & 6,67 & 0,87 & 6 & 326 \\
Kvalita vztahu & $48,60(5,68)$ & 28 & 63 & 0,81 & $13^{*}$ & 326 \\
Úzkostnost & $4,93(4,29)$ & 0 & 21 & 0,88 & 7 & 288 \\
Depresivita & $7,38(4,31)$ & 0 & 21 & 0,77 & 9 & 285 \\
Vztah k dítěti po narození & $0,50(0,36)$ & 0 & 2,55 & 0,88 & 25 & 291 \\
\hline
\end{tabular}

Poznámka: * Položka č. 1 - Jak často se s partnerem shodnete v otázkách víry a náboženství? nekoreluje věcně ani statisticky významně s ostatními položkami a nemá ani uspokojivou korelaci se skóre dimenze $(r=0,281 ; p<0,01)$, proto byla ze škály odstraněna.

\section{Vztah $k$ očekávanému ditěti}

Pro nově vytvořenou metodu Vztahu k očekávanému dítěti byla nejprve provedena položková analýza a explorační faktorová analýza $(\mathrm{EFA})^{2}$, která byla následně doplněna také konfirmační faktorovou analýzou (CFA). Pro testování faktorové struktury byl vzorek náhodně rozdělen na dvě poloviny, na jedné byla provedena EFA, na druhé CFA.

Ze škály byly vyřazeny 2 položky, které se na základě korelační matice (ale také z věcných důvodi̊) jevily jako problematické: Nemohu uvěrit tomu, že opravdu budu mit ditě.; Dělám si starosti, že se během těhotenství nebo porodu mému dítěti něco stane. Zdá se, že první z položek byla některými ženami pochopena pozitivně, některými negativně. Druhá položka byla pravděpodobně pro ženy př́liš náročná na zodpovězení, nevyskytovala se u ní téměř žádná variabilita a ženy na tuto položku odpovídaly negativně.

\footnotetext{
${ }^{2}$ Kompletní výsledky položkové analýzy metody i faktorových analýz jsou na vyžádání u autorek studie.
} 
EFA byla provedena pomocí metody maximální věrohodnosti na náhodně vybraném podsouboru o velikosti 153 respondentek. Dle výsledků Scree Plot grafu byl zvolen šestifaktorový model, který vysvětluje $52,31 \%$ rozptylu. Test dobré shody $\left(\chi^{2}(130)=146,35\right.$; $\mathrm{p}=0,155)$ dokládá smysluplnost řešení. Na základě faktorové analýzy byla vyloučena položka Jsem schopná poznat, zda moje dítě zrovna spí, která sytila dva faktory $(0,325 ; 0,373)$. Ostatní položky mají vysoké faktorové náboje (minimálně 0,394 ) vždy jen na jednom faktoru. Dva ze šesti faktorů mají velmi podobný obsah, který odkazuje na přisuzování vlastností dítěti. Důvodem, proč se v rámci explorační analýzy faktory oddělily, může být podobné znění dvou položek, které vytvořily samostatný faktor. Vzhledem k jejich obsahové podobnosti je však považujeme za ukazatele jednoho aspektu vztahu k očekávanému dítěti a v rámci CFA bude tedy testován model s 5 faktory, ve kterém budou tyto položky sloučeny a přinuceny sytit jeden faktor.

Faktorová struktura zjištěná pomocí EFA byla potvrzena pomocí CFA na druhé polovině vzorku $(\mathrm{N}=140)$. Pomocí metody maximální věrohodnosti bylo doloženo jako smysluplné řešení s 5 faktory, jejichž korelace je možné vysvětlit faktorem vyššího řádu, kterým je celkový vztah k dítěti. Byla povolena korelace reziduí položek 10 a 13 z důvodu jejich velmi podobné formulace. Shoda modelu $\mathrm{s}$ daty je poměrně uspokojivá $\left(\chi^{2}(203)=335,47 ; \quad \mathrm{p}<0,001 ; \quad \mathrm{RMSEA}=0,068 ; \mathrm{TLI}=0,859 ; \quad \mathrm{SRMR}=0,078\right)$. Faktory byly z hlediska obsahu položek, které je sytí, pojmenovány jako: Chování zaměřené na dítě (7 položek, př.: Plánuji si, co budeme spolu s dítětem po jeho narození dělat.), Pocity z těhotenství a ditěte (5 položek, př.: Když pomyslím na své dítě, mé pocity jsou spíše negativní.), Verbálni komunikace směřvovaná na dítě (3 položky, př.: Povídám svému dítěti, co zrovna dělám nebo co se zrovna děje kolem.), Přisuzování vlastností dítěti (5 položek, př.: Myslím, že již ted' je mé dítě osobností s jedinečnými vlastnostmi.) a Vyhýbání se stresu (2 položky, př.: $\mathrm{V}$ průběhu těhotenství se snažím vyhýbat situacím, které by mě mohly stresovat.). Výsledné faktorové řešení zobrazuje obrázek 1. Kromě jednotlivých subškál je možné pracovat s celkovým skóre jakožto ukazatelem síly vztahu k očekávanému dítěti. Jak je patrné $\mathrm{z}$ obr. 1, některé faktory vztahu k očekávanému dítěti jsou silněji syceny celkovým latentním skórem. Pro zkoumání souvislostí s dalšími proměnnými tak doporučujeme pracovat rovněž $\mathrm{s}$ jednotlivými faktory vztahu $\mathrm{k}$ očekávanému dítěti, které mohou přinést diferencovanější pohled na souvislosti očekávaného vztahu. Popisné statistiky a korelace faktorů zobrazuje tabulka č. 2 .

Tab. 2 Popisné statistiky subškál pocit’ovaného vztahu a jejich vzájemné korelace

\begin{tabular}{lccccccc}
\hline & Počet položek & $\mathrm{M}(\mathrm{SD})$ & $\alpha$ & 2. & 3. & 4. & 5. \\
\hline 1. Chování zam. na dítě & 7 & $2,70(0,66)$ & 0,79 & $0,36^{* *}$ & $0,52^{* *}$ & $0,38^{* *}$ & $0,49^{* *}$ \\
2. Pocity z těh. a dítěte & 5 & $3,50(0,52)$ & 0,77 & & $0,39^{* *}$ & $0,28^{* *}$ & $0,26^{* *}$ \\
3. Verb. kom. k dítěti & 3 & $2,50(0,87)$ & 0,79 & & & $0,36^{* *}$ & $0,44^{* *}$ \\
4. Vyhýbání se stresu & 2 & $2,56(0,87)$ & - & & & & $0,31^{* *}$ \\
5. Př́suzování vlast. dítěti & 5 & $2,63(0,65)$ & 0,74 & & & & \\
6. Celkový skór & 22 & $2,82(0,49)$ & 0,88 & & & & \\
\hline
\end{tabular}


Rozložení celkového skóre vztahu k očekávanému dítěti je přibližně normální, nejvíce žen dosahuje středních hodnot a tedy středně silného vztahu k dítěti, méně žen je pak zastoupeno na obou extrémních pólech škály. Vztah k očekávanému dítěti koreluje středně silně a pozitivně se vztahem $\mathrm{k}$ dítěti měřeným po narození dítěte $(\mathrm{r}=0,30, \mathrm{p}<0,001)$, tedy čím silnější vztah žena cítí k očekávanému dítěti, tím silnější vztah k dítěti cítí také po jeho narození.

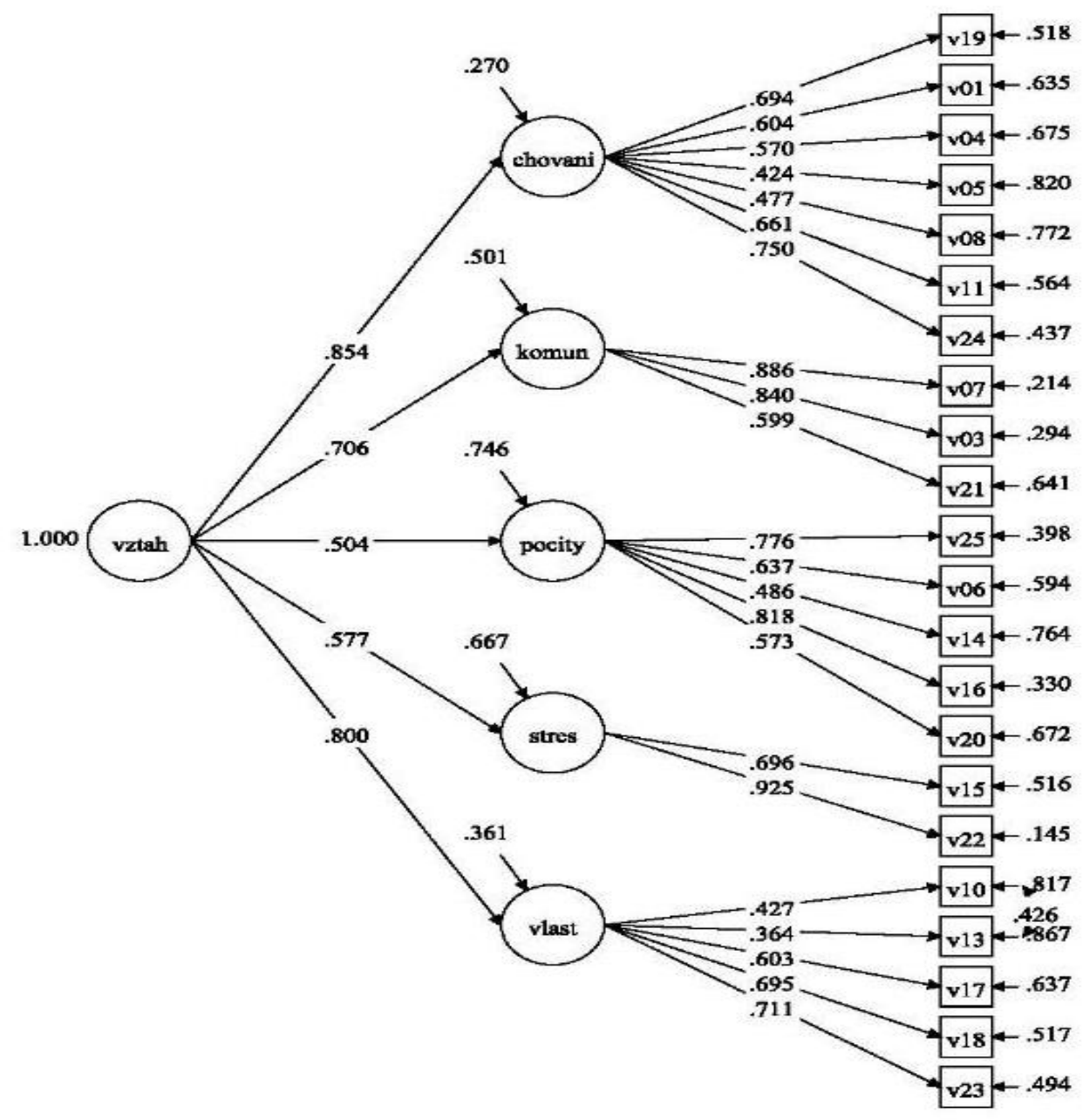

Obr. 1 Faktorová struktura metody Vztahu k očekávanému dítěti ve standardizovaném řešení Poznámky: vztah - vztah kočekávanému ditěti; chováni - chování zaměrené na dité; komun - verbální komunikace směrovaná na ditě; pocity - pocity z těhotenstvi a ditěte; stres - vyhýbáni se stresu; vlast prisuzování vlastností dítěti

\section{Souvislosti vztahu k očekávanému dítěti}

Korelační analýza ukázala statisticky signifikantní korelace vztahu k očekávanému dítěti a jeho jednotlivých aspektů $\mathrm{s}$ depresivitou, $\mathrm{s}$ kvalitou partnerského vztahu a $\mathrm{s}$ vyhýbavostí citové vazby. Tyto výsledky jsou v souladu s předchozími výzkumy. Pearsonova korelace nepotvrdila existenci souvislosti mezi vztahem $\mathrm{k}$ očekávanému dítěti celkově a úzkostností ani úzkostností citové vazby. Vzhledem k teoretickému rámci se však jeví jako smysluplné tyto proměnné přesto do modelu zařadit. Korelační matice zobrazující Pearsonovy korelační koeficienty proměnných je uvedena v tabulce č. 3 . 
Tab. 3 Korelační matice proměnných zařazených do analýzy

\begin{tabular}{lccccc}
\hline & 8. & 9. & 10. & 11. & 12. \\
\hline 1. Pocit'ovaný vztah - celková škála & $0,34^{* *}$ & $-0,21^{* *}$ & $-0,09$ & $0,12^{*}$ & 0,08 \\
2. Pocit'ovaný vztah - chování & $0,23^{* *}$ & $-0,18^{* *}$ & 0,01 & 0,03 & 0,05 \\
3. Pocit'ovaný vztah - pocity & $0,30^{* *}$ & $-0,17^{* *}$ & $-0,10$ & $-0,35^{* *}$ & $-0,29 * *$ \\
4. Pocit'ovaný vztah - komunikace & $0,22^{* *}$ & $-0,11$ & $-0,11$ & $-0,11$ & $-0,05$ \\
6. Pocit'ovaný vztah - vyhýbání se stresu & $0,29 * *$ & $-0,17^{* *}$ & $-0,18^{* *}$ & $-0,18^{* *}$ & $-0,22^{* *}$ \\
7. Pocit'ovaný vztah - vlastnosti & $0,19 * *$ & $-0,12^{*}$ & $-0,04$ & 0,02 & 0,05 \\
8. Kvalita vztahu & & & & & \\
9. Vyhýbavost citové vazby & $-0,20^{* *}$ & $-0,58^{* *}$ & & & \\
10. Úzkostnost citové vazby & $-0,09$ & $-0,49 * *$ & $0,48^{* *}$ & & \\
11. Depresivita & $-0,12^{*}$ & $-0,30^{* *}$ & $0,19 * *$ & $0,36 * *$ & \\
12. Úzkostnost & $-0,08$ & $-0,28^{* *}$ & $0,23 * *$ & $0,41^{* *}$ & $0,74 * *$ \\
\hline
\end{tabular}

Poznámky: ${ }^{*} p<0,05,{ }^{* *} p<0,01$; čím vyšši skór, tím vyšši míra všech konstruktů

Byly zhodnoceny také korelace vztahu $\mathrm{k}$ očekávanému dítěti s demografickými a dalšími proměnnými (tabulka 4). Korelace s věkem ženy je pouze slabá a není statisticky významná $(\mathrm{r}=-0,11 ; \mathrm{p}>0,05)$. Mezi vztahem $\mathrm{k}$ očekávanému dítěti a paritou je středně silná korelace $(r=-0,27 ; p<0,01)$. Korelace $s$ chtěností dítěte matkou je slabá $(r=0,17 ; p<0,01)$, rovněž pak korelace s plánovaností dítěte $(\mathrm{r}=0,15, \mathrm{p}<0,01)$. Na základě předchozích poznatků i teoretických předpokladů se všechny tyto proměnné jeví jako možné důležité faktory pro vytvoření vztahu k očekávanému dítěti, proto budou v rámci lineární regrese kontrolovány, aby bylo možné rozšśřit předchozí poznatky a rovněž určit přínos dalších sledovaných proměnných očištěný od vlivu těchto demografických proměnných.

Tab. 4 Korelace intervenujících proměnných se sledovanými proměnnými

\begin{tabular}{lcccccc}
\hline & $\begin{array}{c}\text { Pocitovaný } \\
\text { vztah }\end{array}$ & Depresivita & Úzkostnost & $\begin{array}{c}\text { Kvalita } \\
\text { vztahu }\end{array}$ & $\begin{array}{c}\text { Vyhýbavost } \\
\text { citové vazby }\end{array}$ & $\begin{array}{c}\text { Úzkostnost } \\
\text { citové vazby }\end{array}$ \\
\hline Věk & $-0,12$ & $-0,15^{*}$ & $-0,13^{*}$ & $-0,07$ & $0,12^{*}$ & $-0,12^{*}$ \\
Parita & $-0,23^{* *}$ & $0,15^{*}$ & $0,15^{*}$ & $-0,22^{* *}$ & $0,19 * *$ & 0,07 \\
Chtěnost & $0,17^{* *}$ & $-0,17^{* *}$ & $-0,08$ & $0,19 * *$ & $-0,05$ & $-0,17^{* *}$ \\
Plánovanost & $0,15^{* *}$ & $-0,16^{* *}$ & $-0,17^{* *}$ & 0,09 & $-0,04$ & $0,13^{*}$ \\
\hline
\end{tabular}




\section{Regresní modely}

Vztahy mezi uvedenými proměnnými byly testovány vícenásobnou lineární regresí se závislou proměnnou vztah $\mathrm{k}$ očekávanému dítěti zvlášt' pro jednotlivé aspekty i pro celkové skóre, přičemž byl kontrolován vliv parity, plánovanosti a chtěnosti dítěte a vliv věku ženy. Vysoká korelace mezi depresivitou a úzkostností $(\mathrm{r}=0,74 ; \mathrm{p}<0,01)$ by mohla regresní model zkreslit, proto byla pro kontrolu vždy do prvního modelu vložena depresivita i úzkostnost, do druhého modelu pouze depresivita a do třetího modelu pouze úzkostnost. Vzhledem $\mathrm{k}$ tomu, že výsledné modely se nezměnily co do podílu vysvětleného rozptylu ani regresních koeficientů ostatních sledovaných proměnných, jsou prezentovány a interpretovány pouze modely, v nichž obě tyto proměnné vystupují společně. Všechny lineární regrese se závislou proměnnou vztah $\mathrm{k}$ očekávanému dítěti byly prováděny metodou Enter. Vzhledem k opakovanému použití testů byla použita Holm-Bonferroniho korekce (Holm, 1973).

Předpoklady použití vícenásobné lineární regrese byly dodrženy - Durbin-Watsonův test potvrdil nezávislost reziduí (pro všechny regresní modely $\mathrm{d}=\mathrm{od} 1,85$ do 1,97), předpoklady normálního rozložení reziduí a jejich homoskedascity byly ověřeny graficky. Kolinearita nedosahovala problematických hodnot (VIF pro všechny modely v hodnotách okolo 1, max. do 2,5).

Nejprve byly testovány 4 regresní modely, jeden pro každý z faktorů škály (Modely 1 - 4). Pro faktor vyhýbání se stresu nebyl regresní model testován, nebot' obsahuje pouze dvě položky, což považujeme v tomto kontextu za problematické.

Model se všemi devíti prediktory se ukázal jako vhodný pro faktory Chováni zaměrené na dítě, Pocity z těhotenství a ditěte a Verbální komunikaci směřrovanou na dítě. U faktoru Přisuzování vlastností dítěti model nebyl signifikantní a vysvětloval pouze velmi malou část rozptylu proměnné $(5 \%)$. U ostatních modelů kombinace prediktorů středně silně koreluje s př́slušným aspektem vztahu $\mathrm{k}$ očekávanému dítěti $(\mathrm{r}=\mathrm{od} 0,31$ do 0,45$)$, přičemž vysvětluje $9-20 \%$ jeho rozptylu. Nejvíce rozptylu je vysvětleno u faktoru Pocitĩ $z$ těhotenství a dítěte, nejméně pak u faktoru Verbální komunikace směrovaná na dítě. Nejvýznamnějším prediktorem ve všech modelech je kvalita partnerského vztahu, dalšími významnými prediktory jsou parita a plánovanost těhotenství. Pro faktor Pocitů z těhotenství a dítěte se ukázala jako významný prediktor také depresivita ženy, pro faktor Chování zaměřeného na ditě pak úzkostnost citové vazby. Vliv ostatních proměnných není v modelu statisticky signifikantní a velikosti účinku jsou rovněž velmi slabé. Výsledky regresních analýz ukazuje tabulka č. 5.

Tab. 5 Lineární regrese se závislou proměnnou vztah k očekávanému dítěti - první část

\begin{tabular}{lcccc}
\hline & \multicolumn{1}{c}{$\mathrm{B}(95 \% \mathrm{CI})$} & $\mathrm{SE}$ B & $\beta$ & $\mathrm{p}$ \\
\hline \multicolumn{2}{l}{ MODEL 1 - Chování zaměřené na dítě } & & & \\
Konstanta & $1,96(0,76 ; 3,15)$ & 0,61 & - & 0,001 \\
Depresivita & $0,05(-0,19 ; 0,29)$ & 0,12 & 0,04 & 0,682 \\
Úzkostnost & $0,09(-0,10 ; 0,29)$ & 0,10 & 0,08 & 0,353 \\
Kvalita vztahu & $0,02(0,01 ; 0,04)$ & 0,01 & 0,16 & 0,038 \\
Vyhýbavost citové vazby & $-0,10(-0,20 ; 0,01)$ & 0,05 & $-0,15$ & 0,061 \\
Úzkostnost citové vazby & $0,07(0,00 ; 0,14)$ & 0,04 & 0,16 & 0,049 \\
Parita & $-0,26(-0,43 ;-0,10)$ & 0,09 & $-0,19$ & 0,003
\end{tabular}


Chtěnost dítěte

Plánovanost dítěte

Věk ženy
$0,16(-0,14 ; 0,46)$

$0,18(-0,03 ; 0,38)$

$-0,02(-0,03 ; 0,01)$
0,15

0,07

0,10

0,10

0,01
0,290

0,096

0,110

$F(9,250)=5,20 ; p<0,001, p^{\prime}<0,001 ; R^{2}=0,16$

\begin{tabular}{lcccc}
\hline \multicolumn{2}{l}{ MODEL 2 - Pocity z těhotenství a dítěte } & & & \\
Konstanta & $2,68(1,83 ; 3,54)$ & 0,44 & - & $<0,001$ \\
Depresivita & $-0,20(-0,37 ;-0,03)$ & 0,09 & $-0,19$ & 0,024 \\
Úzkostnost & $-0,09(-0,23 ; 0,05)$ & 0,07 & $-0,11$ & 0,197 \\
Kvalita vztahu & $0,02(0,01 ; 0,03)$ & 0,01 & 0,21 & 0,006 \\
Vyhýbavost citové vazby & $-0,05(-0,12 ; 0,03)$ & 0,04 & $-0,10$ & 0,203 \\
Úzkostnost citové vazby & $0,05(0,00 ; 0,10)$ & 0,03 & 0,15 & 0,052 \\
Parita & $-0,06(-0,18 ; 0,06)$ & 0,06 & $-0,06$ & 0,344 \\
Chtěnost dítěte & $0,18(-0,04 ; 0,39)$ & 0,11 & 0,10 & 0,105 \\
Plánovanost dítěte & $0,04(-0,11 ; 0,19)$ & 0,08 & 0,03 & 0,615 \\
Věk ženy & $-0,01(-0,02 ; 0,01)$ & 0,01 & $-0,01$ & 0,855 \\
$F(9,250)=6,99 ; p<0,001, p^{\prime}<0,001 ; R^{2}=0,20$ & & & \\
\hline
\end{tabular}

Tab. 6 Lineární regrese se závislou proměnnou vztah k očekávanému dítěti - druhá část

\begin{tabular}{lcccc}
\hline & \multicolumn{1}{c}{$\mathrm{B}(95 \% \mathrm{CI})$} & \multicolumn{1}{c}{ SE B } & $\beta$ & $\mathrm{p}$ \\
\hline \multicolumn{1}{l}{ MODEL 3 - Verbální komunikace směŕovaná na dítě } & & & \\
Konstanta & $1,22(-0,40 ; 2,83)$ & 0,82 & - & 0,140 \\
Depresivita & $-0,13(-0,16 ; 0,11)$ & 0,17 & $-0,07$ & 0,426 \\
Úzkostnost & $0,17(-0,10 ; 0,43)$ & 0,13 & 0,12 & 0,208 \\
Kvalita vztahu & $0,02(-0,01 ; 0,05)$ & 0,01 & 0,15 & 0,063 \\
Vyhýbavost citové vazby & $-0,03(-0,16 ; 0,11)$ & 0,07 & $-0,03$ & 0,703 \\
Úzkostnost citové vazby & $-0,01(-0,10 ; 0,09)$ & 0,05 & $-0,01$ & 0,870 \\
Parita & $-0,26(-0,49 ;-0,03)$ & 0,12 & $-0,15$ & 0,028 \\
Chtěnost dítěte & $0,12(-0,29 ; 0,52)$ & 0,21 & 0,04 & 0,575 \\
Plánovanost dítěte & $0,31(0,03 ; 0,59)$ & 0,14 & 0,14 & 0,033 \\
Věk ženy & $-0,01(-0,03 ; 0,02)$ & 0,01 & $-0,01$ & 0,896 \\
$F(9,250)=2,92 ; p=0,003, p^{\prime}=0,006 ; R^{2}=0,09$ & & & \\
\hline MODEL 4 - Přisuzování vlastností dítěti & $1,63(0,38 ; 2,88)$ & 0,64 & - & 0,011 \\
Konstanta & $-0,06(-0,32 ; 0,19)$ & 0,13 & $-0,05$ & 0,624 \\
Depresivita & & & &
\end{tabular}


Úzkostnost

Kvalita vztahu

Vyhýbavost citové vazby

Úzkostnost citové vazby

Parita

Chtěnost dítěte

Plánovanost dítěte

Věk ženy
$0,13(-0,08 ; 0,33)$

$0,02(0,01 ; 0,04)$

$-0,06(-0,17 ; 0,04)$

$0,05(-0,03 ; 0,12)$

$0,02(-0,16 ; 0,19)$

$-0,17(-0,49 ; 0,14)$

$0,09(-0,13 ; 0,30)$

$-0,01(-0,02 ; 0,02)$
0,10

0,12

0,19

$-0,10$

0,10

0,01

$-0,07$

0,05

$-0,01$
0,216

0,021

0,254

0,209

0,861

0,282

0,772

0,926

$F(9,250)=1,60 ; p=0,117, p^{\prime}=n s . ; R^{2}=0,05$

Byl testován ještě pátý model, ve kterém bylo závislou proměnnou celkové skóre vztahu k očekávanému dítěti s pěti prediktory, které se v předchozích modelech ukázaly jako signifikantní: kvalita partnerského vztahu, depresivita, úzkostnost citové vazby, parita a plánovanost dítěte. Korelace tohoto modelu se vztahem $\mathrm{k}$ očekávanému dítěti klesla oproti předchozím modelům pouze velmi slabě $(\mathrm{r}=0,39)$. Model vysvětluje $15 \%$ rozptylu podobně jako předcházející modely a je lepší než model nulový $(F(5,270)=9,69 ; \mathrm{p}<0,01)$. Signifikantními prediktory jsou kvalita partnerského vztahu $(b(S E)=0,03(0,01) ; \beta=0,31$; $\mathrm{p}<0,001)$, parita $(\mathrm{b}(\mathrm{SE})=-0,16(0,06) ; \quad \beta=-0,16 ; \quad \mathrm{p}=0,008)$ a plánovanost těhotenství $(b(S E)=0,15(0,07) ; \beta=0,12 ; p=0,032)$. Depresivita $(b(S E)=-0,04(0,06) ; \beta=-0,04 ; p=0,497)$ ani úzkostnost citové vazby $(\mathrm{b}(\mathrm{SE})=-0,04(0,02) ; \beta=0,10 ; \mathrm{p}=0,129)$ signifikantními prediktory nejsou.

DISKUZE

Studie se zabývala vztahem k očekávanému dítěti a jeho souvislostmi s vybranými charakteristikami žen ve třetím trimestru těhotenství - s úzkostností, s depresivitou, kvalitou partnerského vztahu a s vyhýbavostí a úzkostností citové vazby. Zároveň byla kontrolována parita, plánovanost a chtěnost dítěte a věk ženy $\mathrm{s}$ cílem podrobněji prozkoumat prínos jednotlivých prediktorů.

Ve výzkumu byla poprvé použita nová škála $\mathrm{k}$ měření vztahu $\mathrm{k}$ očekávanému dítěti vytvořená $\mathrm{s}$ cílem překonat některé limity dosavadních metod a přinést do českého prostředí metodu pro měření tohoto konstruktu. Položky metody byly inspirovány metodami MAAS (Condon, 1993) a PAI (Müller, 1993), přičemž byly konkretizovány, byly vynechány irelevantní údaje a odstraněny podmínkové otázky, které mohou snižovat validitu metody. Z hlediska obsahové validity jsou zastoupeny dř́ve předpokládané aspekty vztahu k očekávanému dítěti, jak je definoval Condon (1993) a Müllerová (1993), a rovněž další aspekty, které jsou podle našeho názoru pro konstrukt relevantní a pokrývají tři klíčové oblasti vztahu k očekávanému dítěti - emoční, kognitivní a behaviorální (Shieh et al., 2001). Navržená škála původně obsahovala 25 položek, z obsahových a empirických důvodů byly 3 položky odstraněny. Metoda se dle konfirmační faktorové analýzy skládá z 5 faktorů: Chování zaměrené na dítě, Pocity z těhotenství a ditěte, Verbálni komunikace směrovaná na dítě, Vyhýbání se stresu a Přisuzování vlastností dítěti. Všech těchto pět faktorů sytí faktor vyššího řádu, který můžeme nazvat celkový vztah k očekávanému dítěti, a který vyjadřuje jak emoční, tak také kognitivní a behaviorální složku vztahu. Síla vztahu k očekávanému dítěti je rozložena rovnoměrně, většina žen ve vzorku má k očekávanému dítěti průměrně silný vztah, 
menší množství žen má vztah k očekávanému dítěti výrazně slabý či výrazně silný. Vztah k očekávanému dítěti měřený touto metodou pozitivně koreluje se vztahem k dítěti měřeným po narození dětí. Ženy, které mají silnější vztah k očekávanému dítěti v době těhotenství, mají rovněž silnější vztah $\mathrm{k}$ dítěti po porodu. Vztahy s ostatními prediktory jsou v souladu s předchozími výzkumy, což svědčí o vhodnosti nástroje pro měření konstruktu vztahu k očekávanému dítěti.

Nebyla zjištěna souvislost vztahu k očekávanému dítěti s věkem ženy, což je ve shodě se závěry dř́vějších výzkumů (např. Condon \& Corkindale, 1997; Wayland \& Tate, 1993; Zachariah, 1994). Ačkoli některé studie slabou souvislost našly (napřr. Yarcheski et al., 2009), zdá se, že věk nastávající matky nemá na podobu vztahu k očekávanému dítěti zásadní vliv. Ženy prvorodičky mají podle našich zjištění mírně silnější vztah k očekávanému dítěti než vícerodičky, což odpovídá předchozím zjištěním (Condon \& Corkindale, 1997; Mercer \& Ferketich, 1995; Yarcheski et al., 2009). Přestože v některých výzkumech vliv parity prokázán nebyl (Berryman \& Windridge, 1996; Condon \& Esuvaranathan, 1990), domníváme se, že vysvětlením může být použití různých metod $\mathrm{k}$ měření vztahu k očekávanému dítěti, respektive jeho odlišných aspektů. V tomto výzkumu se silnější vztah ukázal v oblasti chování zaměřeného na dítě a verbální komunikace směřované na dítě. $Z$ hlediska pocitů směrem k očekávanému dítěti se ženy prvorodičky od vícerodiček nelišily. Naše výsledky tedy naznačují, že ženy, které ještě nemají jiné děti, více interagují se svým dítětem v myšlenkách a představách, více na očekávané dítě hovoří a hovoří o něm rovněž s okolím. Souvislost se zdá logická z hlediska času i energie, který může žena věnovat představám a mluvení na dosud nenarozené dítě. Pro prvorodičky je nastávající role matky novou životní rolí, na kterou se musí adaptovat, což je spojeno s úsilím a explorací vlastního sebeobrazu a identity. Vy̌šsí míra zabývání se dítětem $\mathrm{v}$ myšlenkách a představách, a také směrem navenek v komunikaci $\mathrm{s}$ okolím, se tak zdá důsledkem těchto procesů. Pokud žena vychovává ještě další dítě či děti, nemusí jí zbývat tolik energie a času na to, aby se těmto aspektům věnovala. Vícerodička má rovněž představy o vlastních interakcích $\mathrm{s}$ dítětem a je na mateřskou roli již více adaptovaná. Naopak pocity směrem $\mathrm{k}$ dítěti se mezi ženami prvorodičkami a vícerodičkami neliší, protože pravděpodobně více vychází z celkového emočního prožívání a př́istupu ženy ke vztahům obecně.

Skutečnost, zda je těhotenství plánované či nikoliv, podle našich zjištění souvisí se vztahem $\mathrm{k}$ očekávanému dítěti. Ženy, které těhotenství plánovaly, pocit'ovaly mírně silnější vztah k dítěti než ženy, jejichž těhotenství plánované nebylo. Tyto výsledky jsou ve shodě s předchozími studiemi (Shieh et al., 2001; Yarcheski et al., 2009). Zajímavý je zde pohled na specifické aspekty vztahu k očekávanému dítěti. Plánovanost těhotenství souvisela pouze $\mathrm{s}$ verbální komunikací směrem $\mathrm{k}$ dítěti, nikoli s pocity a chováním zaměřenými na dítě. Lze spekulovat, zda verbální komunikace směrem k dítěti v době těhotenství není svým způsobem pokračováním onoho plánování těhotenství, kdy se matka poté, co ke zplození dítěte došlo, na jeho narození dále připravuje a v průběhu těhotenství na své dítě hovoří. Oproti předpokladům chtěnost dítěte $\mathrm{k}$ síle vztahu k očekávanému dítěti nijak nepřispívala.

Kromě demografických faktorů a faktorů gestačních je vztah $\mathrm{k}$ očekávanému dítěti ovlivněn také faktory teoretickými, ke kterým se řadí deprese a úzkost ženy či vnímaná sociální opora, zejména ve vztahu s partnerem (např. Yarcheski et al., 2009). Oproti předpokladům nebyla prokázána souvislost úzkostnosti se vztahem $\mathrm{k}$ očekávanému dítěti. Předchozí studie prokázaly slabší vztah k očekávanému dítěti u žen s vyšší mírou symptomů úzkosti (Condon \& Corkindale, 1997), ale i opačnou (Allison, Stafford, \& Anumba, 2011) nebo žádnou souvislost (Tsartsara \& Johnson, 2006). Podle výsledků meta-analýzy je vztah 
pouze slabý (Yarcheski et al., 2009). Naše výsledky naznačují, že obecná úzkost se vztahem k očekávanému dítěti nesouvisí, a ženy tak i přes úzkostné symptomy mohou mít silný vztah k očekávanému dítěti.

$\mathrm{V}$ našem výzkumu se nepodařilo prokázat př́mý vliv depresivity na vztah k očekávanému dítěti. Výjimku tvoří dimenze pocitů směrem k dítěti, kde se ukázalo, že ženy $\mathrm{s}$ vyšší mírou depresivity mají mírně slabší vztah k očekávanému dítěti. Tato souvislost se zdá logická vzhledem k negativnímu prožívání, které je pro depresi typické. Depresivní prožívání ženy tak může narušovat její schopnost cítit potěšení a pozitivní emoce ve vztahu $\mathrm{k}$ očekávanému dítěti. Co se týče celkového vztahu k očekávanému dítěti, naše výsledky jsou částečně v rozporu s předchozími studiemi, které prokázaly slabší vztah k očekávanému dítěti u žen s vyšší mírou depresivních symptomů (Condon \& Corkindale, 1997; Lindgren, 2001; McFarland et al., 2011; Goecke et al., 2012). Pokud ovšem vezmeme v potaz samotnou povahu jednotlivých dimenzí, lze považovat naše výsledky za smysluplné. Emoční aspekt vztahu (vyjádřený dimenzí pocitů z těhotenství a ditěte) se zdá depresivitou mírně zasažen, zatímco u kognitivních a behaviorálních aspektů vztahu (jako je chování zaměřené na dítě a verbální komunikace směřovaná na dítě) depresivita pravděpodobně nehraje roli.

Kvalita partnerského vztahu je podle našich výsledků nejvýznamnějším prediktorem vztahu k očekávanému dítěti celkově i specificky jeho jednotlivých aspektů, nejsilněji pocitů směrem $\mathrm{k}$ dítěti. Ženy, které vnímají svůj partnerský vztah jako kvalitní a jsou v něm spokojené, mají silnější vztah k očekávanému dítěti, což je ve shodě s předchozími výzkumy (Barone, Lionetti, \& Dellagiulia, 2014; Hjelmstedt, Widström, \& Collins, 2006; Wachter, 2002; Wayland \& Tate, 1993). Zdá se, že pro ženy, které pocit'ují svůj partnerský vztah jako oporu spíše než jako zdroj stresu, je snazší vytvořit si pozitivní vztah k očekávanému dítěti. Do dítěte, které bude mít $\mathrm{s}$ největší pravděpodobností po narození dobré zázemí od obou rodičů, je možné emočně investovat, protože má z evoluční perspektivy vysokou šanci přežití. Lze též předpokládat, že ženě, která má s partnerem více shody a méně konfliktů, zbývá více energie pro očekávané dítě - přemýšlení a snění o něm, mluvení o něm a $\mathrm{k}$ němu, zpívání, taktilní interakce, všímání si jeho reakcí. Vzhledem $\mathrm{k}$ subjektivitě výpovědí v dotaznících je však možné, že do velké míry jsou výsledky způsobeny i obecnou tendencí ženy k pozitivnímu či negativnímu hodnocení vztahů.

Kromě vnímané kvality vztahu bývá výzkumná pozornost věnována také citové vazbě ženy $\mathrm{k}$ partnerovi. V našem výzkumu nebyla zjištěna souvislost vyhýbavosti citové vazby k partnerovi se vztahem $\mathrm{k}$ očekávanému dítěti celkově ani s jeho jednotlivými aspekty. Souvislost byla patrná pouze na základě korelačního koeficientu, $v$ rámci lineární regrese po zařazení i ostatních prediktorů již vyhýbavost citové vazby významným prediktorem vztahu $\mathrm{k}$ dítěti nebyla. Vyhýbavost citové vazby souvisela ve studii Walshe a kol. (2014) se vztahem $\mathrm{k}$ očekávanému dítěti pouze skrze kapacitu poskytovat péči partnerovi. V předchozích výzkumech nebyla zařazena citová vazba spolu s kvalitou partnerského vztahu a tak je možné, že po kontrole kvality partnerského vztahu již citová vazba nepřispívá k vysvětlenému rozptylu vztahu k dítěti. Vyhýbavost citové vazby tak pravděpodobně souvisí se vztahem k očekávanému dítěti pouze do té míry, do jaké souvisí s kvalitou vztahu. Další studie se mohou zaměřit na možný mediační vliv, který by mezi těmito proměnnými mohl existovat. Naše výsledky dále ukazují pouze slabou pozitivní souvislost úzkostnosti citové vazby specificky s faktorem chování zaměřeného na dítě. Ženy s vyšší mírou úzkostnosti citové vazby k partnerovi si o něco více své dítě představují a myslí na něj, více si plánují dobu po narození apod. Pro celkové skóre vztahu k očekávanému dítěti již úzkostnost citové vazby nehrála roli, což je ve shodě s výsledky studie Walshe a kol. (2014). 
Faktor přisuzování vlastností dítěti nebyl v našem výzkumu spojen s žádným z předpokládaných prediktorů. Domníváme se, že to, zda žena přisuzuje vlastnosti svému očekávanému dítěti, bude pravděpodobně ovlivněno spíše jinými intrapsychickými proměnnými na straně ženy, např. osobnostními charakteristikami.

\section{Limity výzkumu a doporučení pro dalš́i studie}

Limitem studie je použití pouze sebehodnotících dotazníků pro měření všech konstrukti̊ a př́ležitostný výběr vzorku, který s sebou nese riziko nereprezentativnosti vzhledem $\mathrm{k}$ populaci těhotných žen. Vzhledem $\mathrm{k}$ zjišt'ovaným sociodemografickým ukazatelům je pravděpodobné, že náš soubor zcela reprezentativní není. $Z$ hlediska věku byl výzkumný soubor velmi heterogenní, z hlediska vzdělání však převažovaly ženy s vysokoškolským vzděláním a např. socioekonomický status nebyl v naší studii zjišt’ován. Do výzkumu se pravděpodobně nezaregistrovalo mnoho žen z nižších sociálních vrstev či s výrazněji problémovým průběhem těhotenství. Toto omezení se týká naprosté většiny výzkumů vztahu k očekávanému dítěti (např. Alhusen, 2008; Brandon et al., 2009). V dalších výzkumech by bylo zajímavé zaměřit se na opomíjené populace, které v těhotenství nemají zrovna ideální podmínky pro soustředění se na sebe a na očekávané dítě. Zahrnutí odlišných populací by mohlo pomoci ve vyjasnění dalších psychosociálních a kulturních komponent vztahu k očekávanému dítěti.

Náš výzkum vzhledem $\mathrm{k}$ měření $\mathrm{v}$ jednom čase neumožňuje vypovídat o kauzalitě mezi proměnnými. Vycházeli jsme z předpokladu, že jak partnerský vztah, tak deprese či úzkost ženy jsou proměnné, které jsou přítomné před otěhotněním samotným, zatímco vztah $\mathrm{k}$ očekávanému dítěti se utváří právě až v době těhotenství. Je ale nicméně možné, že samotné těhotenství a to, jak žena dítě vnímá, mění její prožívání jak obecně, tak také ve vztahu k partnerovi. Další studie by proto mohly zvážit měření předpokládaných prediktorů dříve v průběhu těhotenství a vztah k očekávanému dítěti až ke konci těhotenství, aby bylo možné hovořit o prediktorech ve smyslu kauzálního vlivu.

Náš vzorek obsahoval přibližně dvě třetiny prvorodiček a třetinu vícerodiček. Vzhledem k nalezené souvislosti parity se vztahem k očekávanému dítěti, ale i s depresivitou, úzkostností, kvalitou partnerského vztahu a vyhýbavostí citové vazby je pravděpodobné, že by se výsledky pro prvorodičky a vícerodičky do určité míry odlišovaly. Výzkumný soubor naší studie však nebyl dostatečně velký pro rozdělení do dvou skupin a provedení analýz pro každou ze skupin zvlášt'. Dalším studiím bychom doporučovali prozkoumat souvislosti vztahu $\mathrm{k}$ očekávanému dítěti odděleně u prvorodiček a u vícerodiček (např. Walsh, Hepper, \& Marshall, 2014), vliv parity by za takových podmínek mohl být objasněn lépe.

Námi vytvořená metoda byla předběžně ověřena $\mathrm{z}$ hlediska faktorové validity a prediktivní validity a byly prezentovány vybrané aspekty poukazující na konstruktovou validitu metody. Za určitý limit metody považujeme pouze dvoupoložkový faktor vyhýbání se stresu, který se budeme snažit rozš́řrit o další položky a v následném výzkumu ověřit.

V tomto výzkumu byla námi sledovanými proměnnými vysvětlena pouze menší část rozptylu vztahu k očekávanému dítěti. Existují tedy další významné proměnné, které mohou podobu vztahu k očekávanému dítěti ovlivňovat. 


\section{Literatura}

Alhusen, J. L. (2008). A literature update on maternal-fetal attachment. Journal of Obstetric, Gynecologic, \& Neonatal Nursing, 37(3), 315-328.

Allison, S. J., Stafford, J., \& Anumba, D. O. (2011). The effect of stress and anxiety associated with maternal prenatal diagnosis on feto-maternal attachment. BMC women's health, 11(1), 33.

Anderson, S. R., Tambling, R. B., Huff, S. C., Heafner, J., Johnson, L. N., \& Ketring, S. A. (2014). The development of a reliable change index and cutoff for the Revised Dyadic Adjustment Scale. Journal of Marital and Family Therapy, 40(4), 525-534.

Austin, M. P., Tully, L., \& Parker, G. (2007). Examining the relationship between antenatal anxiety and postnatal depression. Journal of Affective Disorders, 101(1), 169-174.

Barone, L., Lionetti, F., \& Dellagiulia, A. (2014). Maternal-fetal attachment and its correlates in a sample of Italian women: a study using the Prenatal Attachment Inventory. Journal of Reproductive and Infant Psychology, 32(3), 230-239.

Berryman, J. C., \& Windridge, K. C. (1996). Pregnancy after 35 and attachment to the fetus. Journal of Reproductive and Infant Psychology, 14(2), 133-143.

Bowlby, J. (1969). Attachment and loss: Vol. 1. Attachment. New York: Basic Books.

Brandon, A. R., Pitts, S., Denton, W. H., Stringer, C. A., \& Evans, H. M. (2009). A history of the theory of prenatal attachment. Journal of Prenatal \& Perinatal Psychology \& Health, 23(4), 201-222.

Brockington, I. F., Fraser, C., \& Wilson, D. (2006). The Postpartum Bonding Questionnaire: a validation. Archives of Women's Mental Health, 9(5), 233-242.

Busby, D. M., Christensen, C., Crane, D. R., \& Larson, J. H. (1995). A revision of the dyadic adjustment scale for use with distressed and nondistressed couples: Construct hierarchy and multidimensional scales. Journal of Marital and Family Therapy, 21(3), 289-308.

Cameron, I. M., Crawford, J. R., Lawton, K., \& Reid, I. C. (2008). Psychometric comparison of PHQ9 and HADS for measuring depression severity in primary care. British Journal of General Practice, 58(546), 32-36.

Cannella, B. L. (2005). Maternal-fetal attachment: an integrative review. Journal of Advanced Nursing, 50(1), 60-68.

Coelho, H. F., Murray, L., Royal-Lawson, M., \& Cooper, P. J. (2011). Antenatal anxiety disorder as a predictor of postnatal depression: a longitudinal study. Journal of Affective Disorders, 129(1), 348353.

Condon, J. T. (1993). The assessment of antenatal emotional attachment: Development of a questionnaire instrument. British Journal of Medical Psychology, 66, 167-183.

Condon, J. T., \& Corkindale, C. (1997). The correlates of antenatal attachment in pregnant women. British Journal of Medical Psychology, 70(4), 359-372.

Condon, J. T., \& Esuvaranathan, V. (1990). The influence of parity on the experience of pregnancy: a comparison of first- and second-time expectant couples. British Journal of Medical Psychology, 63, 369-377.

Cranley, M. S. (1981). Development of a tool for the measurement of maternal attachment during pregnancy. Nursing Research, 30, 281-284.

Damato, E. G. (2004). Predictors of prenatal attachment in mothers of twins. Journal of Obstetric, Gynecologic, and Neonatal Nursing, 33, 436-445.

Daňsová, P., Masopustová, Z., Hanáčková, V., Kicková, K., \& Korábová, I. (2016). Metoda Patient Health Questionnaire-9: česká verze. Československá psychologie, 60(5), 468-481. 
Fraley, R. C., Heffernan, M. E., Vicary, A. M., \& Brumbaugh, C. C. (2011). The experiences in close relationships-Relationship Structures Questionnaire: A method for assessing attachment orientations across relationships. Psychological Assessment, 23(3), 615-625. http://dx.doi.org/10.1037/a0022898

George, C., \& Solomon, J. (1996). Representational models of relationships: Links between caregiving and attachment. Infant Mental Health Journal, 17(3), 198-216.

Goecke, T. W., Voigt, F., Faschingbauer, F., Spangler, G., Beckmann, M. W., \& Beetz, A. (2012). The association of prenatal attachment and perinatal factors with pre-and postpartum depression in firsttime mothers. Archives of Gynecology and Obstetrics, 286(2), 309-316.

Hazan, C., \& Shaver, P. (1987). Romantic love conceptualized as an attachment process. Journal of Personality and Social Psychology, 52(3), 511-524.

Hjelmstedt, A., Widström, A. M., \& Collins, A. (2006). Psychological correlates of prenatal attachment in women who conceived after in vitro fertilization and women who conceived naturally. Birth, 33(4), 303-310.

Holm, S. (1979). A simple sequentially rejective multiple test procedure. Scandinavian Journal of Statistics, 65-70.

Kroenke, K., Spitzer, R. L., \& Williams, J. B. (2001). The PHQ-9: validity of a brief depression severity measure. Journal of General Internal Medicine, 16(9), 606-613.

Lindgren K. (2001). Relationships among maternal-fetal attachment, prenatal depression and health practices in pregnancy. Research in Nursing and Health, 24, 203-217.

Martin, A., Rief, W., Klaiberg, A., \& Braehler, E. (2006). Validity of the brief patient health questionnaire mood scale (PHQ-9) in the general population. General Hospital Psychiatry, 28(1), 71 77.

McFarland, J., Salisbury, A. L., Battle, C. L., Hawes, K., Halloran, K., \& Lester, B. M. (2011). Major depressive disorder during pregnancy and emotional attachment to the fetus. Archives of Women's Mental Health, 14(5), 425-434.

Mercer, R. T., \& Ferketich, S. L. (1995). Experienced and inexperienced mothers' maternal competence during infancy. Research in Nursing \& Health, 18(4), 333-343.

Michalčáková, R., Lacinová, L., Bouša, O., Schlesingerová, M. (2011). Strach ze smrti v kontextu citové vazby v období dospívání. In R. Vido, R. Hytych (Eds.), Sociální studia: Smrt (pp. 107-120). Brno: Katedra sociologie Fakulty sociálních studií Masarykovy univerzity.

Mikulincer, M., \& Florian, V. (1999). Maternal-fetal bonding, coping strategies, and mental health during pregnancy - the contribution of attachment style. Journal of Social and Clinical Psychology, $18(3), 255-276$.

Mikulincer, M., \& Shaver, P. (2007). Attachment related mental representations of self and others. In M. Mikulincer \& P. Shaver. Attachment in Adulthood. Structure, Dynamics, and Change (pp.149 187). New York: Guilford Press.

Müller, M. E. (1993). Development of the prenatal attachment inventory. Western Journal of Nursing Research, 15, 199-215.

Pallant, J. F., Haines, H. M., Hildingsson, I., Cross, M., \& Rubertsson, C. (2014). Psychometric evaluation and refinement of the Prenatal Attachment Inventory. Journal of Reproductive and Infant Psychology, 32(2), 112-125.

Shieh, C., Kravitz, M., \& Wang, H. H. (2001). What do we know about maternal-fetal attachment? Kaohsiung Journal of Medical Sciences, 19, 448-454.

Siddiqui, A., \& Hägglöf, B. (2000). Does maternal prenatal attachment predict postnatal mother-infant interaction? Early Human Development, 59(1), 13-25. 
Spitzer, R. L., Kroenke, K., Williams, J. B., \& Löwe, B. (2006). A brief measure for assessing generalized anxiety disorder: the GAD-7. Archives of Internal Medicine, 166(10), 1092-1097.

Tsartsara, E., \& Johnson, M. P. (2006). The impact of miscarriage on women's pregnancy-specific anxiety and feelings of prenatal maternal-fetal attachment during the course of a subsequent pregnancy: An exploratory follow-up study. Journal of Psychosomatic Obstetrics \& Gynecology, 27(3), 173-182.

Tsujino, J. M., Higa, M. O. D., \& Inuihara, T. M. (2002). Specificity of a mother's attachment to her child using the attachment inventory and factors related to attachment: longitudinal research from prenatal to age three. Journal of Prenatal \& Perinatal Psychology \& Health, 17(1), 63-84.

Van den Bergh, B., \& Simons, A. (2009). A review of scales to measure the mother-foetus relationship. Journal of Reproductive and Infant Psychology, 27(2), 114-126.

Wachter, M. K. (2002). Psychological distress and dyadic satisfaction as predictors of maternal-fetal attachment. Dissertation Abstracts International, 63, 2080.

Walsh, J. (2010). Definitions matter: if maternal-fetal relationships are not attachment, what are they? Archives of Women's Mental Health, 13(5), 449-451.

Walsh, J., Hepper, E. G., \& Marshall, B. J. (2014). Investigating attachment, caregiving, and mental health: a model of maternal-fetal relationships. BMC Pregnancy and Childbirth, 14(1), 383.

Wayland, J. \& Tate, S. (1993). Maternal-fetal attachment and perceived relationships with important others in adolescents. Birth, 20, 198-203.

Yarcheski, A., Mahon, N. E., Yarcheski, T. J., Hanks, M. M., \& Cannella, B. L. (2009). A metaanalytic study of predictors of maternal-fetal attachment. International Journal of Nursing Studies, 46(5), 708-715.

Zachariah, R. (1994). Maternal-fetal attachment: influence of mother-daughter and husband-wife relationships. Research in Nursing and Health, 17, 37-44. 


\section{PŘÍLOHA 1:}

Škála Vztah k očekávanému dítěti - znění položek

1. Představuji si, jak asi dítě právě vypadá.

0 - nikdy $\quad 1$ - téměř nikdy 2 -někdy 3 -celkem často 4 -velmi často

2. Jsem schopná poznat, zda moje dítě zrovna spí.

0 - nikdy $\quad 1$ - téměř nikdy 2 - někdy 3 - celkem často 4 -velmi často

3. Povídám svému dítěti, co zrovna dělám nebo co se zrovna děje kolem.

0 - nikdy $\quad 1$ - téměř nikdy 2 - někdy $\quad 3$ - celkem často 4 -velmi často

4. Vyhledávám si informace o vývoji a potřebách dítěte $\mathrm{v}$ tomto stupni těhotenství.

0 - nikdy $\quad 1$ - téměř nikdy 2 - někdy $\quad 3$ - celkem často 4 -velmi často

5. Zdají se mi sny o mém dítěti.

0 - nikdy $\quad 1$ - téměr nikdy $\quad 2$ - někdy $\quad 3$ - celkem často 4 -velmi často

6. Toto těhotenství mě obtěžuje.

0 - nikdy $\quad 1$ - téměr̆ nikdy $\quad 2$ - někdy $\quad 3$ - celkem často 4 - velmi často

7. Promlouvám přímo ke svému dítěti nebo mu zpívám, abych mu vyjádřila své city (například mu říkám, že se na něj těším, že ho mám ráda apod.).

0 - nikdy $\quad 1$ - téměř nikdy 2 - někdy $\quad 3$ - celkem často 4 - velmi často

8. Ř́íam svým blízkým, co dítě v mém břiše dělá.

0 - nikdy $\quad 1$ - téměř nikdy 2 - někdy $\quad 3$ - celkem často 4 -velmi často

9. Nemohu uvěřit tomu, že opravdu budu mít dítě.

0 - nikdy $\quad 1$ - téměř nikdy 2 - někdy 3 - celkem často 4 -velmi často

10. Dítě reaguje na to, co prožívám.

0 - nikdy 1 - téměř nikdy 2 - někdy 3 -celkem často 4 -velmi často

11. Chystám se na to, jak se budu o dítě po jeho narození starat.

0 - nikdy $\quad 1$ - téměř nikdy 2 -někdy 3 -celkem často 4 -velmi často

12. Přepadá mne strach, že se během těhotenství nebo porodu mému dítěti něco stane.

0 - nikdy $\quad 1$ - téměř nikdy 2 - někdy $\quad 3$ - celkem často 4 - velmi často

13. Dítě reaguje na to, co se děje kolem.

0 - nikdy $\quad 1$ - téměř nikdy 2 - někdy $\quad 3$ - celkem často 4 - velmi často

14. Líbí se mi, když cítím pohyby dítěte.

0 - nikdy $\quad 1$ - téměř nikdy 2 - někdy $\quad 3$ - celkem často 4 - velmi často

15. S ohledem na své dítě se snažím nerozčilovat.

0 - nikdy $\quad 1$ - téměř nikdy 2 - někdy 3 -celkem často 4 -velmi často 
16. Mé dítě mi někdy připadá spíš jako něco, co mi komplikuje život.

0 - nikdy $\quad 1$ - téměr nikdy 2 -někdy 3 -celkem často 4 -velmi často

17. Myslím, že již ted' je mé dítě osobností s jedinečnými vlastnostmi.

0 - nikdy $\quad 1$ - téměř nikdy 2 - někdy $\quad 3$ - celkem často 4 -velmi často

18. Moje dítě cítí, když si hladím břicho a dotýkám se ho.

0 - nikdy $\quad 1$ - téměř nikdy 2 -někdy 3 -celkem často 4 -velmi často

19. Plánuji si, co budeme spolu s dítětem po jeho narození dělat.

0 - nikdy $\quad 1$ - téměr̆ nikdy 2 - někdy $\quad 3$ - celkem často 4 - velmi často

20. Cítím lásku ke svému dítěti.

0 - nikdy $\quad 1$ - téměř nikdy 2 -někdy 3 -celkem často 4 -velmi často

21. Oslovuji své dítě jménem nebo jemu určenou přezdívkou (např. Drobeček).

0 - nikdy $\quad 1$ - téměř nikdy 2 -někdy $\quad 3$ - celkem často 4 -velmi často

22. V průběhu těhotenství se snažím minimalizovat stres.

0 - nikdy $\quad 1$ - téměř nikdy 2 -někdy 3 -celkem často 4 -velmi často

23. Moje dítě nějak rozumí tomu, co říkám.

0 - nikdy $\quad 1$ - téměr̆ nikdy 2 -někdy 3 -celkem často 4 -velmi často

24. Představuji si, co asi dítě zrovna dělá.

0 - nikdy $\quad 1$ - téměř nikdy 2 -někdy 3 -celkem často 4 -velmi často

25. Když pomyslím na své dítě, mé pocity jsou spíše negativní.

0 - nikdy $\quad 1$ - téměř nikdy 2 - někdy $\quad 3$ - celkem často 4 - velmi často

Skórování metody:

Chováni zaměřené na dítě:

položky $1,4,5,8,11,19,24$

Pocity z těhotenství a dítěte:

položky (6), 14, (16), 20, (25)

Verbální komunikace směrovaná na dítě:

položky $3,7,21$

Přisuzování vlastností ditěti:

položky $10,13,17,18,23$

Vyhýbání se stresu:

položky 15,22

Položky uvedené v závorce jsou reverzně formulované, je tedy potřeba je rekódovat. 


\section{Údaje o autorkách}

Mgr. Petra Daňsová působí v Institutu výzkumu dětí, mládeže a rodiny Fakulty sociálních studií Masarykovy univerzity v Brně a pracuje jako školní psycholog na základní a mateřské škole. V rámci výzkumu se věnuje zejména ranému vývoji dětí a citové vazbě.

\section{Kontatní údaje:}

Adresa: Fakulta sociálních studií, Masarykova univerzita, Institut výzkumu dětí, mládeže a rodiny, Joštova 10, 60200 Brno

E-mail: dansova@fss.muni.cz

Mgr. Zuzana Masopustová, Ph.D. působí v Institutu výzkumu dětí, mládeže a rodiny Fakulty sociálních studií Masarykovy univerzity v Brně. Dlouhodobě se zajímá o rané symptomy autismu a možnosti rané diagnostiky poruch autistického spektra.

\section{Kontatní údaje:}

Adresa: Fakulta sociálních studií, Masarykova univerzita, Institut výzkumu dětí, mládeže a rodiny

E-mail: zuzana.masopustova@gmail.com

Mgr. Miškóciová Lucie je absolventkou oboru Psychologie na Fakultě sociálních studií Masarykovy univerzity v Brně.

Kontatní údaje:

E-mail: $371861 @$ mail.muni.cz

Doc. Mgr. Lenka Lacinová, Ph.D. je výzkumnou pracovnicí Institutu výzkumu dětí, mládeže a rodiny FSS MU a přednáší vývojovou psychologii na Katedře psychologie FSS MU v Brně. K jejím odborným zájmům patři problematika citové vazby, rodičovského konfliktu a partnerských vztahů.

Kontaktní údaje:

Adresa: Katedra psychologie FSS MU, Joštova 10, 60200 Brno

E-mail: lacinova@fss.muni.cz

Daňsová, P., Masopustová, Z., Miškóciová, L., \& Lacinová, L. (2018). Vztah k očekávanému dítěti a jeho souvislosti s vybranými intra- a interpersonálními charakteristikami žen v třetím trimestru těhotenství. E-psychologie, 12(1), 15-36. Dostupné z http://e-psycholog.eu/pdf/dansova_etal.pdf 